\title{
Academic Self-Efficacy as the Mediator of Adolescent-Parent Secure Attachment Effect towards the Academic Stress of Senior High School Students
}

\author{
Erika Kusuma Putri ${ }^{1 *}$, Arum Febriani ${ }^{2}$ \\ ${ }^{1,2}$ Faculty of Psychology, Universitas Gadjah Mada
}

\author{
Submitted 12 December 2019 Accepted 11 June 2021 Published 30 August 2021
}

\begin{abstract}
This study aimed at examining the role of academic self-efficacy as a mediator of adolescent-parent secure attachment effect towards academic stress of senior high school students. The hypothesis of this study was the adolescent-parent secure attachment effect towards the academic stress of senior high school students is mediated by the academic self-efficacy. Two hundred sixty four 11thgrade senior high school students from three different schools in Yogyakarta were recruited as the research participants. Data collection exerted the adolescent-parent attachment scale, academic stress scale, and academic self-efficacy scale. Mediation analysis was conducted by using the conditional process modelling. Result showed that the adolescent-parent secure attachment affected academic stress of senior high school students is mediated by the academic self-efficacy with an indirect effect coefficient of $-0,199$. The importance of the role of academic self-efficacy in reducing academic stress among students is discussed. The results of this study are expected to serve as evaluation materials for parents to understand that the success of teenagers in school is not only the responsibility of the teachers and the school. Future researchers could also add a variable of adolescent-peers attachment to expand more knowledge on the topic.
\end{abstract}

Keywords: academic self-efficacy; secure attachment; academic stress

School, as a formal education institution, is a facility that functions to provide education, direction, guidance, and training with the aim of developing the student potentials (Ahmad, 2010). Particularly for students in adolescence period, schools have an important impact on a number of aspects of development; such as self-identity, self-confidence, a picture of life, interpersonal relationships, the concept of a social system other than family, and preparing adolescents in future career choices (Papalia \& Feldman, 2009).

Adolescents have a quite heavy duty because they are faced with a series of demands imposed on them, both from family, school, and social environment (Nurmaliyah, 2014). Senior high school students, compared to junior high school students, face greater pressure because of the demand to start planning a career in the future by determining the choice of major in higher education (Nurmi, 2004). High demands from various parties often become stress triggers among high school students, especially those who do not have readiness and discipline in learning (Taufik \& Ardi, 2013). Academic stress is known as stress that is caused by learning processes or other learning-related activities, usually experienced by students (Desmita, 2014). Muhammad Ramli Rahim as Chairperson of the Indonesian Teachers Association (IGI) stated that there is a phenomenon of academic stress occurs in Indonesian education. Academic stress has also been a popular topic of educational research. For example, Andi (1998) found that student's academic stress is triggered, among others, by the severity of demands and academic pressure in schools. There are several studies that show a general picture of academic stress that occurs among senior high school students in Indonesia, such as research conducted by Gusti Ayu Putri (2017) in 367 high school students in Andir District, Bandung, which showed that

${ }^{*}$ Address for correspondence: erika_kusumaputeri@yahoo.com 
$33 \%$ of students had high academic stress, 35.4\% of students had moderate academic stress and 31,6\% of students had low academic stress. Other research, such as by Taufik and Ardi (2013) on 319 Public High School students in Padang found 15\% of students experienced low academic stress, $71.8 \%$ of students experienced moderate academic stress, and 13.2\% of students experienced high academic stress. Similar to the study above, research conducted by Suyono, Triyono, and Handarini (2016) in 5 senior high schools and vocational schools in Gresik showed that 10 out of 20 students experienced academic stress. The source of their academic stress is the burden of learning too many subjects, supplemental tutoring outside of school hours, a series of tasks that must be completed immediately, pressure and demands from parents and the school for achievement, and dislike for certain subjects and teachers.

Stress among students caused by learning processes or things related to learning activities is called academic stress (Desmita, 2014). Muhammad Ramli Rahim as Chairperson of the Indonesian Teachers Association (IGI) stated that there is a phenomenon of academic stress that occurs in the world of Indonesian education. Academic stress among students is triggered, among others, by the severity of demands and academic pressure in schools (Andi, 1998). There are several studies that show a general picture of academic stress that occurs among senior high school students in Indonesia, such as research conducted by Gusti Ayu Putri (2017) in 367 senior high school students in Andir District, Bandung, which showed that $33 \%$ of students had high academic stress, $35,4 \%$ of students had moderate academic stress and $31,6 \%$ of students had low academic stress. Furthermore, the research conducted by Taufik and Ardi (2013) in 319 State Senior High School students in Padang showed that $15 \%$ of students experienced low academic stress, $71,8 \%$ of students experienced moderate academic stress, and $13,2 \%$ of students experienced high academic stress. Similar to the study above, research conducted by Suyono. and Handarini (2016) in 5 senior high schools and vocational schools in Gresik showed that 10 out of 20 students experienced academic stress. The source of their academic stress is the burden of too many subjects because it was supplemented by tutoring outside of school, a series of tasks that must be completed immediately, pressure and demands from parents and the school for achievement, and dislike for certain subjects and teachers.

According to Albana (2007) academic stress on students are influenced by several factors, one of them is family. Family takes important part in the development of their children from the start and becomes the place for the first education and primary for children. Since the kids were born, family, especially parents, have been involved actively in child-rearing to fulfill the needs of their children. All forms of interaction with the parents will become something of an experience for the children, which would develop into an attachment (J. Santrock, 2013).

Bowlby (1982) defined the attachment as an emotional attachment that is stable to certain people in life. Adolescent-parent attachment is defined as an emotional attachment tied between parents and teenagers, which is an continuity from the attachment developed by the children with parents since from the start and will continue throughout the life span (Cassidy \& Shaver, 1999). According to Bowlby (1982), the secure attachment that exists between parents and adolescents manifested by the responsiveness of parents to adolescents can predict positive adjustments when adolescents are in stressful conditions, including academic stress. This opinion is supported by Brar (2013) which shows that the secure attachment that exists with parents provides a strong foothold for teenagers in resolving academic conflicts and is effectively able to deal with academic pressure. Conversely, if the relationship between teenagers and parents is not good, this will make teenagers suffer more in facing academic stress (Kim \& Lee, 2013). In conditions full of academic demands, teenagers may feel alone, confused, and depressed because of the lack of support, warmth, and positive communication with parents.

Although several studies have shown the role of adolescent-parent secure attachment on academic stress, it is possible that the relationship is not a direct relationship. In other words, it is important to uncover the mechanisms that underlie how the secure attachment that adolescents have with parents can influence the decline in adolescents academic stress. One of the factors suspected of being a mediator in the relationship between adolescent-parent secure attachment to academic stress is academic self-efficacy.

According to Bandura (1997), self-efficacy is an individual's belief in his or her ability to organize actions so that the goals he wants are achieved. Academic self-efficacy can be interpreted as students' beliefs in their ability to succeed in performing certain academic tasks (Lent et al., 1997). Academic 
self-efficacy, as well as general self-efficacy, can be formed due to secure attachment with parents. Several studies have shown that secure attachment with parents will encourage the formation of more positive teen "self" including self-efficacy in various domains, among others social and career decision-making (Wright \& Perrone, 2010) as well as academic (Tavakolizadeh et al., 2015). In details, the research conducted by Tavakolizadeh et al. (2015) it was found that secure and supportive relationships with mothers during childhood influenced the development of individual confidence and trust in establishing relationships with others in the future. This strong self-confidence causes individuals to be able to deal with and resolve problems with a positive attitude which is an important foundation for self-esteem formation and academic self-efficacy.

Academic self-efficacy is closely related to academic stress and is one component that can reduce academic stress (Durand \& Barlow, 2003; Zajacova et al., 2005). Students who have high academic self-efficacy will believe that they are able to deal with the problem effectively and are determined to work on the various tasks and demands imposed on them until they are finished. Furthermore, students with high academic self-efficacy view difficulties as challenges and will actively seek new situations. This will have an impact on the reduced fear of failure and improve problem solving skills (Schultz \& Schultz, 2013). This opinion is supported by Vahedi et al. (2014) which showed that increasing academic self-efficacy in students can affect the decrease in academic stress which will ultimately improve students' mental and physical health.

Based on this explanation, this study examined the relationship between adolescent-parent secure attachment, academic self-efficacy, and academic stress in senior high school students. The hypothesis in this study was that academic self-efficacy is a mediator of the adolescent-parent secure attachment effect towards the academic stress in senior high school students. Students who have secure attachments, which are manifested in warm and positive interactions with parents will encourage more positive representations of teenagers, one of which is self-efficacy (Fering \& Taska in (Agarwal \& Poojitha, 2017). Through high academic self-efficacy, students are expected to have the ability to manage academic demand's thus they have low academic stress.

\section{Literature review}

Bowlby (1982) defined the attachment as an emotional attachment that is stable to certain people in life. Adolescent-parent attachment is defined as an emotional attachment tied between parents and teenagers, which is a continuity of the attachment developed by the children with parents since the beginning and will continue throughout the life span (Cassidy \& Shaver, 1999). According to Bowlby (1982), the secure attachment that exists between parents and adolescents manifested in the responsiveness of parents to adolescents can predict positive adjustments when adolescents are in stressful conditions, including experiencing academic stress. This opinion is supported by Brar (2013) which showed that the secure attachment with parents provides a strong foothold for teenagers in resolving academic conflicts so that they are effectively able to deal with academic pressure. Conversely, if the relationship between teenagers and parents is not good, this will make teenagers suffer more when facing academic stress (Kim \& Lee, 2013). In conditions full of academic demands, teenagers may feel alone, confused, and depressed because of the lack of support, warmth, and positive communication with parents. According to Bandura (1997), self-efficacy is an individual's belief in his or her ability to organize actions so that the goals he wants are achieved. Academic self-efficacy can be interpreted as students' beliefs in their ability to succeed in performing certain academic tasks (Lent et al., 1997). Academic self-efficacy, as well as general self-efficacy, can be formed due to secure attachment with parents. Several studies have shown that secure attachment with parents will encourage the formation of more positive teen "self" including self-efficacy in various domains, including social and career decision-making (Wright \& Perrone, 2010) as well as academics (Tavakolizadeh et al., 2015). In details, the research conducted by Tavakolizadeh et al. (2015) found that secure and supportive relationships with mothers during childhood influenced the development of individual confidence and trust in establishing relationships with others in the future. This strong self-confidence causes individuals to be able to deal with and resolve problems with a positive attitude which is an important foundation for self-esteem formation and academic self-efficacy. Academic self-efficacy is closely related to academic stress and is one component that can reduce academic stress (Durand \& Barlow, 2003; Zajacova et al., 2005). Students who have high academic self-efficacy will 
believe that they are able to deal with the problem effectively and are determined to work on the various tasks and demands imposed on them until they are finished. Furthermore, students with high academic self-efficacy view difficulties as challenges and will actively seek new challenging situations. This will have an impact on the reduced fear of failure and improvedproblem solving skills (Schultz \& Schultz, 2013). This opinion is supported by Vahedi et al. (2014) which showed that increasing academic self-efficacy in students can affect the decrease in academic stress which will ultimately improve students' mental and physical health.

\section{Method}

\section{Research participants}

Research participants were purposively selected based on the following criteria: (1) high school students in Yogyakarta; (2) between $16-17$ of ages. Following recruitment there were 264 students aged between 16-17 years provided consent to participate in the study. Among these participants, $57.2 \%$ were females and $42.8 \%$ were males. They were $11^{\text {th }}$ grade high school students coming from three different schools in Yogyakarta: 91 students of Public High School X, 87 students of Public School Y, and 86 students of Public School Z.

\section{Measuring Instrument}

\section{Adolescent-Parent Attachment Scale}

The Adolescent-Parent Attachment scale consists of 23 items compiled based on the attachment aspects developed by Armsden and Greenberg (1987), including: trust, alienation and communication. Examples of the items on this scale are "I tell all the problems to my parents" and "I can count on my parents when experiencing difficulties". Participants were asked to respond to each item using a 5-point Likert scale, ranging from 0 (Very Incompatible) to 4 (Very Appropriate). In this study, The Adolescent-Parent Attachment Scale has good reliability with Cronbach's $\alpha$ coefficient of 0.933 .

\section{Academic Stress Scale}

The Academic Stress Scale is structured based on the aspects of academic stress proposed by Robotham (2008), including cognitive functions, behavioral functions, physiological functions and emotional / affective functions. The Academic Stress Scale in this study amounted to 22 items with Cronbach's $\alpha$ coefficient of 0.866. An example of the item on this scale is "I have difficulty concentrating in learning when thinking about the amount of tasks that need to be done" and "The density of learning activities causes the immune system to decrease that I get sick easily". Participants in this study were asked to respond to each item using a 5-point Likert scale, ranging from 0 (Very Incompatible) to 4 (Very Appropriate).

\section{Academic Self-Efficacy Scale}

The Academic Self-Efficacy Scale consist of 22 items based on the dimensions of academic self-efficacy Bandura (1997), covering: generalizations and strengths. This scale has a Cronbach's $\alpha$ coefficient of 0.883. An example of the item on this scale is "I don't easily give up on difficult tasks" and "I am not easy to give up on difficult tasks". Participants were asked to respond to each item using a 5-point Likert scale, ranging from 0 (Very Incompatible) to 4 (Very Appropriate).

\section{Analysis}

The data obtained were analyzed using macro PROCESS from Hayes (2013) to examine the role of mediation or indirect effect. 


\section{Results}

Table 1 shows the mean, standard deviation, and correlation for all measurements. As predicted, the adolescent-parent secure attachment was positively correlated with academic self-efficacy, but negatively correlated with academic stress.

Table 1

Correlation among variables

\begin{tabular}{llllll}
\hline Variable & Mean & SD & 1 & 2 & 3 \\
\hline & 64.22 & 12.824 & $0.410^{* *}$ & $-0.317^{* *}$
\end{tabular}

1. Adolescent-Parent Secure Attachment

\begin{tabular}{lccccc}
\hline 2. Academic Self-Efficacy & 49.42 & 11.337 & $0.410^{* *}$ & & $-0.587^{* *}$ \\
\hline 3. Academic Stress & 41.38 & 11.308 & $-0.317^{* *}$ & $-0.587^{* *}$ & \\
& & & & \\
${ }^{* *} \mathrm{p}<0.01$ & & & &
\end{tabular}

To examining whether academic self-efficacy mediates the adolescent-parent secure attachment effect on academic stress, mediation analysis was performed using macro PROCESS from Hayes (model 4). This mediation hypothesis testing is based on testing the significance of indirect effects, using 5000 bootstrap simulation.

Based on the results of the analysis, it is known that the adolescent-parent secure attachment effect to academic stress is mediated by academic self-efficacy. This was indicated by the value of $F=$ 70.734 with $p<0.05$. Path a showed that there is a significant effect between parents and adolescents' secure attachment to academic self efficacy, $B=0,363, S E=0.050, p=0.001(p<0.05)$. This means that the higher the adolescent-parent secure attachment, the higher the academic self-efficacy of students. Furthermore, path $\mathrm{b}$ also showed there is a significant effect between academic self-efficacy on academic stress, $B=-0.548, S E=0.055, p=0.001(p<0,05)$. This means that the higher the academic self-efficacy, the lower the student's academic stress, and vice versa. Finally, path $c^{\prime}$ showed no effect of adolescent-parent secure attachment to academic stress by controlling academic self-efficacy, $B=-0,081, S E=0.048, p=0.095(p>0.05)$. Furthermore, the results of the analysis showed the coefficient of indirect effect of the adolescent-parent secure attachment to academic stress through the mediator of academic self-efficacy of -0.199 with $95 \%$ CI $[-0.276,-0.131]$. Because zero was not contained in the range of $95 \%$ confidence intervals, it can be concluded that indirect effect is significant and means academic self-efficacy is a mediator of the adolescent-parent secure attachment effect towards the academic stress in senior high school students. The estimated relationship between variables can be seen in Figure 1.

\section{Discussion}

The results of this study indicate that adolescent-parent secure attachment effect towards the academic stress in senior high school students is mediated by academic self-efficacy. Adolescents who have secured attachments with parents will have a positive self-representation that encourages the formation of high academic self-efficacy. Through high academic self-efficacy, adolescents will have the confidence to manage academic demands thus they have low academic stress. Conversely, adolescents who have low secure attachment with parents will have low academic self-efficacy, which has an effect on increasing academic stress among students. Based on these results, the hypothesis in this study was accepted.

The results of this study reinforce the theory that while throughout adolescence individuals will rely less on parents as attachment figures and begin to turn to peers as their attachment figures, secure attachments with parents remain important because parents have a role in a number of aspects of 


\section{Figure 1}

Schematic Results of Estimated Relations among Variables

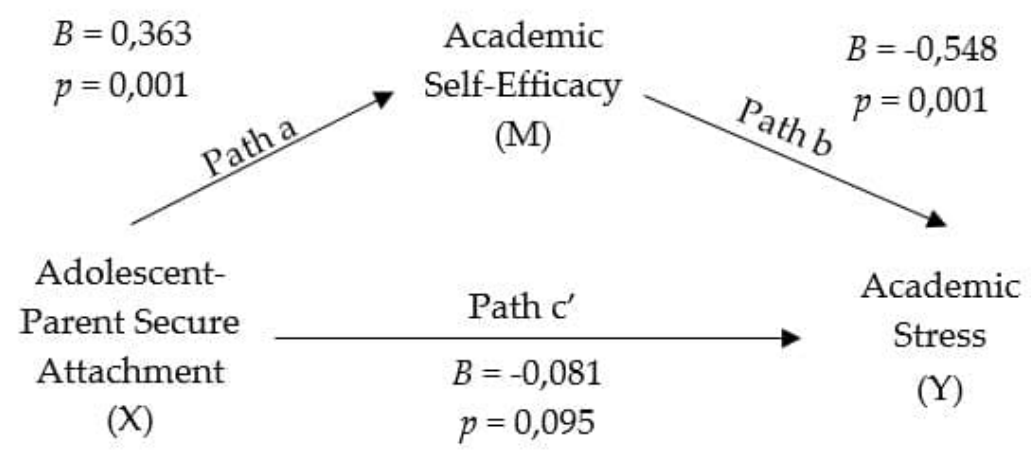

adolescent self-development such as development of self-identity, social competence, and adolescent emotional well-being (Allen \& Land, 1999). According to Baumrind (1967), adolescent who have secure attachments with parents are cared for in an authoritative parenting style. Parents who have an authoritative parenting style are attentive, more open, flexible, having good communication skills, and avoiding punishment as a form of discipline (Baumrind, 1967); (J. W. Santrock, 2007). In the academic context, parents with authoritative parenting style will provide demands and control the actions of adolescents accompanied by good communication. Parents will pay attention to the needs, abilities and academic difficulties experienced by adolescent and involve them in discussion to make joint decisions. That is unlike the case with adolescents who have an insecure attachment with parentsdue to parents' authoritarian parenting style. This parenting style will demand high adherence, punish teenagers if they violate their demands, does not provide opportunities to self-regulate and to express their desires and needs (Setiono, 2011). In other words, parents with authoritarian parenting style will only burden teenagers by making academic demands, without good two-way communication so parents do not understand the needs, abilities and academic difficulties experienced by teenagers.

The adolescent-parent secure attachment is defined as the emotional bond between parents and adolescents, which is a continuation of the attachments that children have with parents from the beginning of their lives (Cassidy \& Shaver, 1999). According to Armsden and Greenberg (1987), there are three aspects of attachment including trust, communication and alienation. Children who succeed in developing trust in their parents at the beginning of their lives will have the belief that their environment is a safe place and that they are individuals who are accepted in the environment. This positive view of self and the environment will shape what Bowlby termed as positive internal working model (Bretherton \& Munholland, 2008). The formation of this positive internal working model will influence the formation of teenager's self, one of which is the formation of academic self-efficacy described by Bandura as a result of cognitive processes.

Bandura (1997) explained that academic self-efficacy is the result of cognitive processes in the form of decisions, beliefs, or judgments about the extent to which individuals measure their ability to carry out certain tasks and actions. This confidence in his ability will influence the individual's interpretation of the environmental situation which will ultimately influence individual behavior. In other words, a secure attachment with parents are manifested in trust, harmonious communication and acceptance from parents; that will encourage the formation of a positive internal working model. This positive internal working model will influence the positive assessment of teenagers about life situations that will affect the courage, confidence, and confidence of teenagers in dealing with problems effectively. This construct of thought is an important foundation for forming academic self-efficacy in teenagers (Faraghi \& Abedini, 2015).

Furthermore, academic self-efficacy in teenagers can be improved through harmonious communication between parents and teenagers which is referred to as a source of verbal persuasion efficacy (Bandura, 1997). Bandura explained that reinforcement from parents about their ability to succeed in overcoming academic difficulties would be able to improve teenagers' academic 
self-efficacy. Self-efficacy increases when teenagers who are facing difficulties obtain confidence and reinforcement from parents that they are able to face these difficulties. Verbal persuasion can improve teenagers' academic self-efficacy to the extent given in a realistic context. This opinion is supported by research conducted by Hasan, Hossain, and Islam Hasan et al. (2014) which showed that there is a positive and significant relationship between verbal persuasion and academic self-efficacy. The results of the study indicate that verbal persuasion received by students from other people such as parents, teachers, and peers can improve students' academic self-efficacy which ultimately has a positive impact on their academic performance.

In the academic context, self-efficacy plays an important role for students in interpreting situations that occur around them and is one of the abilities that is useful for reducing academic stress (Albana, 2007); (Durand \& Barlow, 2003). Teens with high academic self-efficacy will interpret the academic situation positively and feel confident that they are able to deal with various academic demands. Teenager's belief in their ability will affect their effective stress coping behavior which leads to reduced academic stress. This is in line with the opinion expressed Bandura (1995) that students with high academic self-efficacy have the ability to manage academic demands that will influence emotional states such as stress, anxiety and depression, as well as motivation and academic achievement. This opinion is supported by the research of Sim and Moon (2015) which showed that academic self-efficacy has a positive effect on adjusting life in college. Students with high academic self-efficacy have low stress levels and better self-adjustment in life on campus. Similar to the study, Arslan (2017) research on senior high school students also showed that students' high academic self-efficacy is able to reduce their academic stress.

Furthermore, Bandura (1997) explained the effect of high academic self-efficacy on decreasing academic stress among students through a process called the affection process. In the affection process, Bandura explained that academic self-efficacy affects how much pressure students feel when facing academic difficulties. Students who believe that they are able to overcome difficult situations will feel calm and not anxious. In overcoming academic difficulties, students who have high academic self-efficacy will use the strategy and design a series of activities to change the situation. In this context, academic self-efficacy affects the decrease in academic stress and anxiety through coping behavior (Bandura, 1997). This opinion is in line with research conducted by Natovova and Chylova (2014) which showed that individuals who have high self-efficacy are able to manage problems in an effective way and tend to use positive coping strategies. One of the positive coping strategies is diverting attention from stressful activities / situations to other more positive situations or activities.

Furthermore, Bandura (1995) argued that the level of academic self-efficacy students have will affect their stress coping abilities in difficult academic situations. Students who have high academic self-efficacy will consider academic difficulties as a challenge and they will try to use various ways to deal with these difficulties. In addition, students with high academic self-efficacy also assume that academic difficulties are an opportunity for them to learn new mastery. Unlike the case with students who have low academic self-efficacy, they will easily give up when facing academic difficulties and believe that the efforts to overcome these academic difficulties will be in vain (Schultz \& Schultz, 2013).

The findings in this study are in line with the research conducted by Luzzo and McWhirter (2011) which showed that students who have high academic self-efficacy will be able to overcome obstacles related to stress factors felt by students during their study period. In addition, Yang (2004) also revealed that individuals with low self-efficacy would believe that every problem they faced would be difficult to resolve. These negative beliefs can increase stress, fatigue and ineffectiveness in solving problems.

\section{Conclusion}

Based on the results of the research and analysis conducted, it can be concluded that the adolescent-parent secure attachment effect towards academic stress in senior high school students is mediated by academic self-efficacy. The secure attachment that exists between parents and adolescents can improve students'academic self-efficacy, thus causing reduction of students' academic stress. The higher the adolescent-parent secure attachment, the higher the academic self-efficacy of students. The 
higher the student's academic self-efficacy, the lower the student's academic stress. The study results can provide some relevant implications in the field of education in Indonesia. Noting the increasing phenomenon of academic stress among students in Indonesia, the results of this study are expected to serve as evaluation materials for parents to understand that the success of teenagers in school is not only the responsibility of the teachers and the school. Parents have an important role and must actively participate in their children's education so that teenagers have high academic self-efficacy. Family and school should not only require teenagers to excel, but also try to understand what they experience and feel. Families and schools can work together to assist teenagers, for example: in arranging schedule activities, making education plans and how to achieve them, and helping teenagers to overcome their academic difficulties. This positive support and communication will have an impact on the more positive self-development of teenagers, one of which is the formation of academic self-efficacy that will affect the teenager academic stress reduction. It will ultimately have a positive impact on their academic performance at school.

\section{Recommendation}

This study had several limitations. First, this research was only conducted at Senior High Schools (SMA) in the Special Region of Yogyakarta. Secondly, this study was only conducted on 11th-grade students who might cause differences in the results of the study if it was done on 10th and $12^{\text {th }}$ grade students. The $11^{\text {th }}$ grade students are generally already in a comfortable condition and have adapted to the school environment; whereas in $10^{\text {th }}$ grade students, they are faced with situations of adjustment to the new school environment. Meanwhile, $12^{\text {th }}$ grade students, they are faced with preparation to face the National Examination (UN). This difference in situations and conditions can affect differences in the results of research if done at different grades. Future research will need to collect data from a larger number of samples from other cities in Indonesia. Larger sample sizes from various cities will provide results that can be generalized to high school students in Indonesia. Researchers should add a variable of adolescent-peers attachment. In adolescence, the attachment with parents begins to shift to attachment with peers. Through the addition of adolescent-peers attachment variable, the research can hopefully reveal deeper and more comprehensive aspects of attachment in influencing the formation of self-concept in adolescents.

\section{Acknowledgment}

The author would like to thank the schools and teachers who have allowed researchers to collect data and students who have participated in the data collection process.

\section{Funding}

The author received no funding for the study.

\section{Author's Contribution}

The author design measuring instruments, conducted data collection, supervised data collection, analyzed the data, and wrote the manuscript.

\section{Conflict of interest}

The author declares no conflict of interest in this study.

\section{Orcid ID}

Erika Kusuma Putri 0000-0002-6610-2400

Arum Febriani 0000-0002-2114-1318 


\section{References}

Agarwal, S., \& Poojitha, S. R. (2017). Parent and peer attachment and assertiveness in college students. The International Journal of Indian Psychology, 4(3), 138-150.

Ahmad, J. N. (2010). Penggunaan school well-being pada sekolah menengah atas (sma) bertaraf internasional sebagai barometer evaluasi sekolah. Jurnal UI untuk Bangsa Seri Sosial dan Humaniora, 1, 100-112.

Albana, J. M. (2007). Sulit belajar (langkah praktis mengatasi stres belajar [difficulty to study (practical steps to deal with learning stress]. Jakarta, Prestasi Pustaka Anak.

Allen, J., \& Land, D. (1999). Attachment in adolescence. In J. \& P. R. Shaver (Eds.), In cassidy. New York, Handbook of Attachment: Research, Theory, Clinical Applications. : The Guilford Press.

Andi. (1998). Kekerasan di sekolah akibat stres akademik [violence at school due to academic stress]. http: //www.edupost.id

Armsden, G. C., \& Greenberg, M. T. (1987). The inventory of parent and peer attachment: Individual differences and their relationship to psychological well-being in adolescence. Journal of Youth and Adolescence, 16(5), 427-454.

Arslan, N. (2017). Investigating the relationship between educational stress and emotional self efficacy. Universal Journal of Educational Research, 5(10), 1736-1740. https://doi.org/10.13189/ujer.2017. 051010

Bandura, A. (1995). Self efficacy in changing societies. New York, Cambridge University Press.

Bandura, A. (1997). Self-efficacy: The exercise of control.

Baumrind, D. (1967). Child care practices anteceding three patterns of preschool behavior. Genetic Psychology Monograph, 75, 43-88.

Bowlby, J. (1982). Attachment and loss: Attachment vol. 1. New York, Basic.

Brar, R. (2013). Coping strategies and parental attachment as predictors of academic stress in adolescents. International Journal of Humanities and Social Science, 2(10), 47-51.

Bretherton, I., \& Munholland, K. A. (2008). Internal working models in attachment relationships: Elaborating a central construct in attachment theory. New York, Handbook of Attachment Second Edition: Theory, Research, Clinical Applications. : The Guilford Press.

Cassidy, J., \& Shaver, P. R. (1999). Handbook of attachment: Research, theory, and clinical applications. New York, The Guilford Press.

Desmita. (2014). Psikologi perkembangan peserta didik [the developmental psychology of students [reducing student's academic stress using self-instruction technique]. Bandung, PT Remaja Rosdakarya.

Durand, V. M., \& Barlow, D. (2003). Essentials of abnormal psychology. California, Wadsworth/Thomson Learning.

Faraghi, M., \& Abedini, M. (2015). The relationship between attachment style with self efficacy and academic performance of secondary school students in bandar abbas. European Online Journal of Natural and Social Sciences, 4(1), 716-719.

Gusti Ayu Putri, T. H., Suryani. (2017). Hubungan stres akademik dengan kecanduan internet pada remaja sma di kecamatan andir kota bandung [the relationship between academic stress and internet addiction among high school in andir district bandung. Faletehan Health Journa, 4(4), 223-227.

Hasan, Z., Hossain, T., \& Islam, A. (2014). Factors affecting self-efficacy towards academic performance: A study on polytehnic students in malaysia. Advances in Environmental Biology, 8(9), 695-705.

Hayes, A. F. (2013). Introduction to mediation, moderation, and conditional process analysis: Regression-based approach. New York, The Guilford Press.

Kim, E., \& Lee, M. (2013). The reciprocal longitudinal relationship between the parent-adolescent relationship and academic stress in korea. Social Behavior and Personality, 41, 1519-1532.

Lent, R. W., Brown, S. D., \& Gore, P. A. (1997). Discriminant and predictive validity of academic self-concept, academic self-efficacy, and mathematics-specific self-efficacy. Journal of Counseling Psychology, 44(3), 307-315. https://doi.org/10.1037/0022-0167.44.3.307

Luzzo, D. A., \& McWhirter, E. H. (2011). Sex and ethnic differences in the perception of educational and career-related barriers and levels of coping efficacy. Journal of Counseling Development, 79(1), $61-67$. 
Natovova, L., \& Chylova, H. (2014). Is there a relationship between self-efficacy, well-being and behavioural markers in managing stress at university students. Journal on Efficiency and Responsibility in Education and Science, 7(1), 14-18. https:/ / doi.org/10.7160/eriesj.2013.070302

Nurmaliyah, F. (2014). Menurunkan stres akademik siswa dengan menggunakan teknik self-instruction [reducing student's academic stress using self-instruction technique]. Jurnal Pendidikan Humaniora, 2(3), 273-282.

Nurmi, E. (2004). Age, sex, social class, and quality of family interaction as determinants of adolescent?s future orientation: A developmental task interpretation. Adolescence, $22,8$.

Papalia, D. E., \& Feldman, R. D. (2009). Human development (11th ed). New York, McGraw Hill Companies Inc.

Robotham, D. (2008). Stress among higher education students: Toward a research agenda. Higher Education, 56, 735-746.

Santrock, J. W. (2007). Adolescence. Boston, McGraw-Hill.

Santrock, J. (2013). Life-span development. New York, McGraw-Hill.

Schultz, D., \& Schultz, E. S. (2013). Theories of personality. Wodsworth, Cengage Learning.

Setiono, K. (2011). Psikologi keluarga [family psychology]. Bandung, P.T. Alumni.

Sim, H.-S., \& Moon, W.-H. (2015). Relationships between self-efficacy, stress, depression and adjustment of college students. Indian Journal of Science and Technology, 8. https: / / doi.org / $10.17485 / \mathrm{ijst} / 2015 / \mathrm{v} 8 \mathrm{i} 35 / 86802$

Suyono., T., \& Handarini, D. M. (2016). Keefektifan teknik relaksasi untuk menurunkan stres akademik siswa sma [the effectiveness of relaxation technique to reduce academic stress in high school students]. Jurnal Pendidikan Humaniora, 4(2), 115-120.

Taufik, I., \& Ardi, Z. (2013). Kondisi stres akademik siswa sma negeri di kota padang. Jurnal Konseling dan Pendidikan, 1(2), 143-150.

Tavakolizadeh, J., Tabari, J., \& Akbari, A. (2015). Academic self efficacy: Predictive role of attachment styles and meta-cognitive skills. Procedia-Social and Behavioral Sciences, 171, 113-120. https: / / doi.org/10.1016/j.sbspro.2015.01.096

Vahedi, L., Tabrizi, N. T., Kolahdouzan, K., Chavoshi, M., Rad, B., Soltani, S., \& Ghojazadeh, M. (2014). Impact and amount of academic self-efficacy and stress on the mental and physical well-being of students competing in the 4th olympiad of iranian universities of medical sciences. Journal Research and Development in Medical Education, 3(2), 99-104. https: / / doi.org/10.5681/rdme. 2014.020

Wright, S. L., \& Perrone, K. M. (2010). An examination of the role of attachment and efficacy in life satisfaction. The Counseling Psychologist, 38, 6. https://doi.org/10.1177/0011000009359204

Yang, H. J. (2004). Factors affecting student burnout and academic achievement in multiple enrolment programs in taiwan's technical-vocational colleges. International Journal of Education Development, 24, 283-301.

Zajacova, A., Lynch, S. M., \& Espenshade, J., T. (2005). Self-efficacy, stress, and academic succes in college. Research in Higher Education, 46(6), 677-706. https: / / doi.org / 10.1007 / s11162-0044139-z 